\title{
Genetikai és epigenetikai faktorok polycystás ovarium szindróma esetén
}

\author{
Herczeg Zita ${ }^{1}$ - Vanya Melinda dr. ${ }^{2,3,4}$. Szili Károly dr. ${ }^{1,3,4}$ \\ Dézsi Csilla dr. ${ }^{4}$ - Nagy Zsolt dr. ${ }^{4}$ - Szabó János dr. ${ }^{1}$ \\ Szegedi Tudományegyetem, Általános Orvostudományi Kar, Szent-Györgyi Albert Klinikai Központ, \\ ${ }^{1}$ Orvosi Genetikai Intézet, ${ }^{2}$ Szülészeti és Nőgyógyászati Klinika, Szeged \\ ${ }^{3}$ Kecskeméti Főiskola, Tanítóképző Főiskolai Kar, \\ Egészségtudományi és Egészségfejlesztő Kutató Csoport, Kecskemét \\ ${ }^{4}$ Mediteam Zrt., Szeged
}

\begin{abstract}
A polycystás ovarium szindróma kialakulásának pontos mechanizmusa a mai napig nem tisztázott, de környezeti, illetve genetikai tényezók nagy valószínúséggel szerepet játszhatnak a kialakulásában. Ezt a megállapítást alátámasztja a gyakran előforduló családi halmozódás is. A praenatalis időszakban elszenvedett teratogén hatások a postnatalis időszakban kialakuló krónikus betegségek kifejlődéséhez vezethetnek. A szerzők polycystás ovarium szindrómában a genetikai és epigenetikai tényezők szerepével foglalkozó, 2016. január 1-jéig publikált szakirodalmi közlemények alapján szakirodalmi kutatást végeztek. Jelen összefoglaló közlemény célja e különleges betegségcsoportra való figyelemfelhívás, valamint e kórképek genetikai és epigenetikai hátterének ismertetése. Orv. Hetil., 2016, 157(32), 12751281 .
\end{abstract}

Kulcsszavak: polycystás ovarium szindróma, genetika, epigenetika

\section{Genetic and epigenetic factors of polycystic ovary syndrome}

The development of polycystic ovary syndrome and its exact pathophysiological mechanism is still unclear, but environmental and genetic factors likely play a role. Exposition to teratogenic effects during the prenatal development can lead to chronic diseases in the postnatal period. This finding confirms the common familial aggregation as well. A literature search was conducted up to January 1, 2016 for articles dealing with the genetic or epigenetic factors of polycystic ovary syndrome. This review will discuss the current understanding of the genetic basis and clinical presentation of this disease.

Keywords: polycystic ovary syndrome, genetics, epigenetics

Herczeg, Z., Vanya, M., Szili, K., Dézsi, Cs., Nagy, Zs., Szabó, J. [Genetic and epigenetic factors of polycystic ovary syndrome]. Orv. Hetil., 2016, 157(32), 1275-1281.

(Beérkezett: 2016. február 23.; elfogadva: 2016. május 29.)

\begin{abstract}
Rövidítések
ACTH $=$ adrenokortikotrop hormon; AEPCOS = Androgen Excess and PCOS Society; $\mathrm{AR}=$ androgénreceptor; CAG repeat $=$ citozin-adenin-guanin ismétlődés; FSH $=$ folliculus stimulating hormone; FTO = alpha-ketoglutarate-dependent dioxygenase; GnRH = gonadotropin releasing hormone; GWAS $=$ genome-wide association studies; INSR $=$ inzulinre ceptor-gén; LH = luteinizáló hormon; NIH = National Institutes of Health; PCOS = polycystás ovarium szindróma; SHBG = szexhormonkötő globulin; SNP = single nucleotide polymorphism; SRDA = szteroid -5 - $\alpha$-reduktáz
\end{abstract}

A polycystás ovárium szindróma (PCOS) definíciója a szindróma 1935-ös, Stein és Leventhal általi leírása óta a gyarapodó ismeretanyag ellenére a mai napig sem tisztázott.

\section{Prevalencia}

A PCOS-t az egyik leggyakrabban előforduló endokrin betegségnek tartják a reproduktív korú nók körében [1$3]$. Pontos előfordulási gyakoriságát nem egyszerü meg- 
határozni, részben a diagnosztikus kritériumok nem pontos tisztázása, illetve változása miatt [2-5]. A PCOS prevalenciája a NIH-kritériumokat figyelembe véve körülbelül $6-8 \%$ a kaukázusi populációban. A rotterdami kritériumok használata esetén az előfordulási gyakoriság megnő, mintegy 15-25\%-ra. Az AE-PCOS ajánlásokat használva pedig 10-15\% körül találjuk az előfordulási gyakoriságot [3-7].

\section{Patomechanizmus}

A polycystás ovarium szindróma etiológiája a mai napig nem tisztázott, annak ellenére, hogy jelentős eredmények születtek a témában. A mai napig nem ismerünk olyan mechanizmust, amely egyedül felelőssé tehető e sokarcú szindróma megjelenéséért.

A kutatások jelenlegi álláspontja alapján a PCOS kialakulásában döntő szerepe van a mellékvesekéreg és a petefészek fokozott androgéntermelésének, a hypothalamus-hypophysis-petefészek tengely múködészavarának és az inzulinrezisztenciával összefüggő hyperinsulinaemiának [1-3].

\section{A hypothalamus-hypophysis-petefészek tengely müködészavara}

A PCOS patogenezise során egy olyan neuroendokrin diszfunkcióval állunk szemben, amelyben megváltozik a hypothalamusban termelődő GnRH hormon termelődésének a frekvenciája és amplitúdója [1, 2].

A fokozott GnRH-aktivitás következményeként növekszik az LH szekréciója, ugyanis a GnRH-szekréciós frekvencia növekedése az LH $\beta$-alegység transzkripcióját serkenti. A pulzáció növekedése beindítja és serkenti a follisztatin gén expresszióját is, amely az LH-szekréciót serkenti, míg az FSH-termelést gátolja. A gátolt $\mathrm{FSH}-$ termelés miatt az FSH nem éri el azt a szintet, amely elegendő az androgén-ösztrogén átalakuláshoz a folliculusokban. A folliculusok növekedési és fejlődésbeli zavara miatt pedig anovuláció alakul ki $[1,2]$. Így jön létre a PCOS-re jellemző egyik hormonális eltérés, az emelkedett $\mathrm{LH} / \mathrm{FSH}$ arány $(>2: 1)$.

A hypothalamusban termelődő GnRH pulzatilis frekvenciájának a növekedése hátterében a GnRH-termelő sejtek intrinszik zavara, az alacsony progeszteron és az endogén opioidok csökkent gátlása állhat [1-3].

Az endogén opioidok a GnRH-, LH- és a prolaktinszekréció szabályozói. Az endogén opioidok gátolják a GnRH szekrécióját. Így az opioidok szintjének csökkenése szintén serkenti a gonadotrop sejtek GnRH-szekrécióját. Tehát feltételezhető, hogy a GnRH/LH szekréciót a csökkent opioid és dopaminerg gátlás befolyásolja $[4,5]$.

A hypophysealis LH túltermelését a GnRH-frekvencia növekedése mellett fokozza az anovuláció miatt hiányzó progeszteron. A viszonylag alacsony progeszteron így nem tudja érvényesíteni negatív feed-back hatását. Az emelkedett ösztrogénszint pedig pozitív visszacsatolás útján serkenti az emelkedett LH-termelést.

PCOS-ben szintén gyakori hormonális eltérés a hyperprolactinaemia, amely szintén a csökkent centrális dopaminerg hatás következményének tulajdonítható [3-5].

\section{A petefészek-theca-sejtek androgéntermelésének a növekedése}

A polycystás ovarium szindróma kórélettanára jellemző az ovariumdiszfunkció, amelyet a hypothalamushypophysis-petefészek tengely zavara, illetve a hyperinsulinaemia hoz létre [4].

A petefészek androgénszintézisének a kulcsenzime a 17- $\alpha$-hidroxiláz és 17/20-liáz, a P450cl7 enzimkomplex részei. Ezeknek az enzimeknek fokozott a múködése PCOS-ben. Az enzimkomplex fokozott aktivitását számos hatás elősegíti PCOS-ben, így megemlíthető az LH, az IGF-1 és maga az inzulin is. Az emelkedett LH és inzulin serkenti az ovarialis theca-sejtek androgénprodukcióját. Az ovarium theca-sejtjeiben megnövekszik az androgének szintézise, theca-sejt-szaporulat alakul ki és stroma-hyperplasia [4].

\section{A mellékvesekéreg fokozott androgéntermelése}

A PCOS-re jellemző hyperandrogenismus kialakulásában nemcsak az ovarium androgén szintézisének a zavara áll, hanem a mellékvesékben is kóros androgénszintézist figyelhetünk meg [4].

PCOS-betegeknél magasabb szérumtesztoszteron, szabad tesztoszteron és androszténdion mérhető. PCOS-es nők körülbelül 25\%-ában fokozott mellékveseandrogéntermelést figyelhetünk meg. Ennek háttere feltehetőleg a kortizolmetabolizmus zavarában keresendő. Több vizsgálat eredménye alapján arra következtethetünk, hogy a fokozott kortizolmetabolizmus hátterében az 5- $\alpha$-reduktáz és a 11 - $\beta$-hidroxisztreoid-dehidrogenáz múködészavara, fokozott aktivitása állhat, illetve az inzulin is megnöveli a mellékvesekéreg ACTH iránti érzékenységét [4].

\section{NIH-kritériumok}

Az egységes szemlélet kialakítására 1990-ben került sor a National Institutes of Health $(\mathrm{NIH})$ útmutatása alapján. Ezen a nemzetközi találkozón fogalmazták meg a NIHkritériumokat a PCOS diagnózisának a felállításához. Ezek szerint PCOS diagnosztizálható anovuláció vagy menstruációs zavar és hyperandrogenismus laboratóriumi, klinikai jelei (hirsutismus/acne) esetén, ha más endokrin kórkép kizárható. Ebben a kritériumrendszerben nem tesznek utalást az ovariumok morfológiájára. A kritériumrendszer rámutat, hogy többféle betegség is okozhat hasonló tüneteket, amelyek kizárása elengedhetetlen része a diagnózisnak [1-7]. 


\section{Rotterdami kritériumok}

Egy európai és amerikai szakértőkből álló bizottság 2003-ban Rotterdamban megállapodott, hogy PCOS áll fenn, ha a következő három állítás közül legalább kettő érvényes, és más endokrin betegség kizárható: 1. anovuláció vagy oligoanovuláció, 2. androgéntúlsúly klinikai vagy laboratóriumi tünetei, 3 . polycystás ovariumok észlelése ultrahanggal.

Mindezek ellenére a nézeteltérések továbbra is fennmaradtak a PCOS diagnózisát illetően, amit egy 2005-ös tanulmány is jól illusztrál. Ebben a közleményben megállapították, hogy a szülész-nőgyógyászok többsége alapvetőnek tartotta az ultrahangon megjelenő ovariumok polycystás képét a diagnózis kimondásához, míg az endokrinológusok a hirsutismust és anovulációt tekintették a két legfontosabb diagnosztikus kritériumnak [2-7].

Éppen ezért a rotterdami kritériumokat megalkotó bizottság számos tagja létrehozta az Androgen Excess Societyt, és irányelvajánlásukban visszakanyarodtak az 1990-es NIH-kritériumokhoz. Jelenleg a rotterdami kritériumok követése ajánlott [8-10].

\section{Androgen Excess and PCOS Society}

$\mathrm{Az}$ Androgen Excess and PCOS Society (AEPCOS) 2006-ban egy kompromisszumot javasolt a két diagnosztikus kritérium között. Mivel a PCOS egy hyperandrogenismussal járó kórkép, a hirsutismus/acne és/vagy hyperandrogenaemia és az anovuláció elengedhetetlen feltétele a diagnózisnak. Kiemelik, hogy a rotterdami kritériumokban megengedett további kombinációk csupán a kórkép enyhébb variánsai, és a polycystás ovarium képe is tisztázandó $[4,10]$.

\section{Genetikai faktorok}

Epidemiológiai adatok alapján egyértelmüen felvetődik a PCOS kialakulásában a genetikai faktorok szerepe [816]. Kutatások alapján látható, hogy monozigóta ikrekben a PCOS előfordulása kétszer gyakoribb, mint dizigótákban. A genetika szerepét a kórkép létrejöttében csak erősíti a családban való halmozottság előfordulása. Elsőfokú nőrokonok között tízszer gyakoribb a hyperandrogenaemia és inzulinrezisztencia. Elsőfokú férfi rokonok között pedig háromszor gyakoribb a kopaszság vagy a fokozott szőrnövekedés. Mindezek arra utalnak, hogy a PCOS autoszóm domináns módon öröklődik. A PCOS egy multifaktoriális eredetú kórkép. A multifaktoriális eredetű kórképek lényege, hogy a poligénesen meghatározott genetikai hajlam a környezet provokáló hatására válhat manifeszt betegséggé. A PCOS oligogénes öröklődésű betegségek közé tartozik. A PCOS kialakulásában fontos faktor az elhízás, ami már önmagában is egy részben genetikailag meghatározott állapot [14-16].

\section{Asszociációs vizsgálatok}

Poli- és oligogénesen öröklődő betegségek génjeinek a felkutatása asszociációs tanulmányok segítségével folyik. Az asszociációs vizsgálatok alapja a genom szekvenciájának a feltérképezése, és ezen belül azoknak a régióknak a megtalálása, amelyek eltéréseket hoznak létre. Azokat az eltéréseket keresik, amelyek egy adott betegséggel feltehetőleg összefüggésbe hozhatók. Ezeket az eltéréseket nevezzük SNP-nek (single nucleotide polymorphism). SNP-k az emberi genom körülbelül 1\%-át teszik ki.

A genomszekvencia megismerése lehetővé tette annak a lehetőségét is, hogy ezeket a polimorfizmusokat génekhez tudjuk kötni.

Asszociációs vizsgálatokban két lehetôség adódik a kandidáns (jelölt) gének feltérképezésére. Első lehetőség, hogy olyan családokat vizsgálnak, ahol az adott betegség több családtagot érint, ezt nevezzük linkage analízisnek. Ebben az esetben a vizsgált családokban halmozottan fordul elő az adott betegség, azaz több tagot is érint. Az érintettek mintáit vizsgálják, amely több száz gént jelent, és azokat keresik, amelyek együtt öröklődnek a tünetekkel.

A második lehetőség a linkage analízis mellett a kandidáns gén megtalálására, hogy két csoportot hoznak létre. Az egyik csoport tagjait képezik a betegek, a másik csoport pedig egészséges emberekből áll. Így több száz beteget vizsgálnak illesztett kontroll mellett. Azokat a géneket keresik fel, amelyek elméleti megközelítés alapján összefüggésbe hozhatók az adott betegséggel. Amennyiben az egészséges és a betegcsoport tagjai között egy adott variáns előfordulási gyakorisága azonos, akkor feltehetőleg nem játszik szerepet a betegség kialakulásában. Azok a variánsok, amelyek eltérő gyakorisággal fordulnak elő a két összehasonlított csoportban, azok összefüggésbe hozhatók a betegség kialakulásával [14-16].

\section{Genom-wide association studies}

A genom-wide association studies (GWAS) a betegek genomjának szinte a teljes szekvenciáját képes feltérképezni egyetlen lépésben. GWAS-vizsgálatokban az SNP-k kutatása automatizált módon történik. Mind a beteg, mind az egészséges egyének genomszekvenciáját meghatározzák, és csipek segítségével több százezer SNP-t határoznak meg, és azokat keresik, amelyek gyakorisága eltér a két vizsgált csoport között [14].

\section{Kandidáns gének felkutatása PCOS-ben}

PCOS-ben a kandidáns gének felkutatása asszociációs vizsgálatokkal igen nehézkes, tekintve, hogy a PCOS patogenezise nagyon komplex és nem teljesen tisztázott, így könnyen elkerülheti a figyelmet egy-egy gén. Ezzel szemben a GWAS képes ezt a problémát kiküszöbölni, és olyan adatokat szolgáltat, amelyek segítenek megérteni egy-egy betegség kialakulását. 
A genetikai vizsgálatok korlátai PCOS-ben:

1. Retrospektív diagnózis nehézségei menopauza után.

2. A betegség heterogenitása: különböző kritériumok használata a diagnózisfelállításra. Több fenotípus létezik, amelyek kialakulásában lehet, hogy más gének vesznek részt.

3. Etiológia nem tisztázott.

4. A PCOS-re jellemző a szubfertilitás és a magasabb vetélések száma, amelyek a transzgenerációs genetikai tanulmányokra negatív hatással vannak.

A következőkben kiemelésre kerül néhány olyan aszszociációs tanulmány, amely pozitív eredményt hozott.

\section{Kandidáns gének elhízásban}

A PCOS és elhízás közötti kapcsolat már régóta ismert. A PCOS-es nők 38-88\%-a túlsúlyos vagy elhízott. Az elhízás kialakulásában is feltételezhetők örökletes tényezők, illetve a PCOS és elhízás gyakori együttes előfordulása arra enged következtetni, hogy vannak olyan kandidáns gének, mint az FTO, amely mindkét betegség kialakulásában szerepet játszik.

Az FTO-gének egyes variánsainak a hordozása emelkedett testtömegindexszel jár, mindez fokozott kockázatot jelent PCOS kialakulására. Az FTO-gén a 16q12.2 kromoszómán található. Az FTO rs9939609 SNP és más variánsai magasabb BMI-vel járnak.

Az FTO-gén rs1421085 SNP-t vizsgálták középeurópai populációban, PCOS-es $(\mathrm{n}=207)$ és kontroll$(\mathrm{n}=100)$ csoportokban. A homozigóta $\mathrm{C} / \mathrm{C}$ variáns gyakoribb előfordulását találták túlsúlyos vagy metabolikus szindrómás egyénekben a sovány PCOS-es nőkhöz viszonyítva [14]. Tanulmányukban szintén kimutatták, hogy az elhízással kapcsolatos gének (mint az FTO és a melanocortin receptor 4 gén - MC4R) szintén magasabb BMI-értékhez vezet PCOS-ben, de nem játszanak fontos szerepet a szindróma kialakulásában. Mivel a PCOS és elhízás között szoros kapcsolat van, érdemes lehet más, zsírmennyiséget befolyásoló gének eltéréseinek a vizsgálata, keresése, amelyek szerepet játszhatnak a PCOS kialakulásában [15-19].

\section{Kandidáns gének a szteroidszintézisben}

A hyperandrogenaemia a PCOS fontos tünete. A szteroid-bioszintézis összetett, számos kandidáns gén szerepét vetheti fel.

A CYP11A a P4501 lal enzimet kódolja, amely a szteroidszintézis-sebesség meghatározó lépése. Ez alakítja át a koleszterint pregnenolonná. CYPl lA kandidáns gént vizsgálva nem találtak összefüggést az 5-ös allél esetén PCOS-sel, azonban összefüggést találtak a 4-es alléllel [18-20].

A PCOS patogenezisében fontos szerepet játszik az 5- $\alpha$-reduktáz, amely a tesztoszteront alakítja át dihidro- tesztoszteronná. PCOS-ben az 5- $\alpha$-reduktáz aktivitása megnövekedett [21-25]. Az 5- $\alpha$-reduktáz két izoformáját tudjuk elkülöníteni, amelyek két különböző génen kódoltak (SRD5Al és SRD5A2). Mindkét izoformának ugyanaz a szerepe, a tesztoszteron átalakítása erősebb dihidrotesztoszteronná. Az SRD5Al haplotípusnak mind a PCOS kialakulásában, mind a hirsutismusban szerepe van, míg az SRD5A2-nek csak a PCOS kialakulásában. Mindemellett az SRD5A2-nek megtalálták egy olyan variánsát (Val89Leu) is, amely alacsonyabb 5- $\alpha$-reduktáz-aktivitást eredményez, és összefüggésbe hozták a PCOS kialakulási esélyének a csökkentésével [26-28]. Az aromatáz enzim alakítja át az androgéneket ösztrogénné. Bebizonyosodott, hogy a granulosasejtekben a kontrollokhoz képest PCOS esetén csökkent az aromatázaktivitás.

$\mathrm{Az}$ androgénreceptor az AR-gén által kódolt és az Xq11-1238 locus felelős az aktivitásért. A receptort három funkcionális domén alkotja: transzaktivációs domén, DNS-kötő domén és a ligandkötő domén. Az AR transzkripciós aktivitása fordítottan arányos a CAGrepeatek számával. E polimorfizmusok ismétlődése alacsony vagy magas AR-aktivitást eredményezhet. Ezért a csökkent CAG-ismétlődések száma, megnövekedett androgénreceptor-aktivitás magyarázhatja a néhány PCOS-fenotípust. Mindazonáltal van egy pár tanulmány, amely nem bizonyította ezt az összefüggést [27, 28].

A nemihormon-kötő globulin (SHBG) szintje általában alacsony hyperandrogenismusos betegeknél, különösen PCOS esetén. Az SHBG egy homodimer glikoproteinből áll és kódol egy 4 kb-os gént, a 17p12-p1348,49-et. Egy pentanukleotid-ismétlést eredményező polimorfizmus befolyásolja az SHBG-gén transzkripciós aktivitását. Számos eredmény arra utal, hogy a hosszabb allélt hordozó betegek esetén alacsonyabb volt az SHBG szintje. Ezek alapján az SHBG-gén potenciális jelölt gén a PCOS patogenezisében [29-32].

\section{Kandidáns gének a gonadotropinszabályozásban}

Az LH-t kódoló gén alegysége, amely felelős az LH-specificitásért, már feltárt PCOS esetén. Az LH kétpontos mutációi - Trp8Arg és Ilg15Thr - szerkezeti változásokat, a variáns LH-molekulákat eredményeznek (V-LH), amely fokozott in vitro aktivitást és csökkent in vivo felezési időt mutat a nem mutáns formához képest. Azonban az V-LH in vivo aktivitása a hyperandrogenismust nem magyarázza. Az elhízott PCOS-betegek nagyobb gyakorisággal heterozigóták V-LH-ra az elhízott nem PCOS-betegekhez képest. Ugyanakkor más vizsgálatok nem találtak összefüggést PCOS esetén. Összességében a V-LH funkcionális szerepe nem tisztázott, de úgy tűnik, hogy nem döntő fontosságú a PCOS patogenezisében [29-32]. 


\section{Kandidáns gének inzulinrezisztencia esetén}

$\mathrm{Az}$ inzulinreceptor egy heterotetramer glikoprotein, amely két és két $\beta$-alegységekből áll és kódolja az inzulinreceptor-gént (INSR) [32-39]. Újabban egy átfogó tanulmányban Urbanek és mtsai [37] bizonyították az INSR szerepét PCOS esetén; 367 genetikailag érintett családot azonosítottak Európában. Siegel és mtsai vizsgálták az INSR tirozinkináz-domén SNP-t és összefüggést találtak a PCOS-sel [38]. Az inzulin kötődésekor a receptor autofoszforilezését $\beta$-alegység végzi. A tirozinkináz-aktivitás után előállított autofoszforiláció foszforilezi inzulin receptor szubsztrátok (IRS), mint például az IRS-1-et és IRS-2-t. Amikor az IRS-1 diszfunkcionális, az IRS-2 a fó hírvivője az inzulinjelnek, de aktivitása megköveteli a magasabb inzulinkoncentrációt. Több polimorfizmusa az IRS1 és IRS2 génnek szerepet játszhat az inzulinrezisztencia létrejöttében. Az IRS-1 Gly972Arg-polimorfizmus és az IRS-2 Glyl057Asp SNP-je kimutatták, hogy fokozhatja a 2-es típusú diabetes mellitus kialakulását [39-42].

\section{Epigenetikai faktorok}

Nagyszámú fejlődési rendellenesség, illetve krónikus betegség van, amelyeknek etiológiája multifaktoriális eredetú, és a genetikai hajlam a környezet provokáló hatására manifeszt betegséggé alakulhat. Ezeknek a betegségeknek a kialakulásában nagy szerepe lehet az epigenetikai módosulásoknak. Ezek olyan mechanizmusokat foglalnak magukba, amelyek nem egy adott gén meghibásodására vezethetők vissza.

Az epigenetikai mechanizmusok dinamikus és egyben reverzibilis kromatinváltozások, amelyek nem változtatják meg a DNS bázissorendjét. Tehát a DNS-ben szekvenciálisan nem kódolt változásról van szó. Ezek a módosulások gyakran stabilak és öröklődnek. Transzgenerációs hatásuk miatt nemcsak az adott egyén feno-, illetve genotípusát határozzák meg, hanem az utódokra is hatással lehetnek.

Az epigenetikai módosulások közül a DNS-metiláció a legjelentősebb. A sejtszintű folyamatokban van jelentősége, mint például X-kromoszóma-inaktiváció, hisztonkód kialakulása, imprinting. A metiláció az eukarióta sejtekben elsősorban a citozinbázisokat érinti. A pirimidingyưrű ötödik szénatomjának a metilációját a DNS metiltranszferázok végzik. A citozinmetiláció az úgynevezett CpG-nukleotidszekvenciákon történik, amelyek a promóterek környékén helyezkednek el, ennek következményeként a gén transzkripciós aktivitása csökken [43-46]. Az epigenetikai módosulások számos nőgyógyászati betegség kialakulásában szerepet játszhatnak.

\section{Epigenetikai hatások PCOS-ben}

Ugyan a PCOS kialakulásának a pontos mechanizmusa a mai napig nem tisztázott, de a környezeti, illetve a gene- tikai tényezők nagy valószínúséggel szerepet játszhatnak kialakulásában. Ezt a megállapítást alátámasztja a nemritkán megfigyelhető családi halmozódás is. A praenatalis időszakban - amely az emberi fejlődés epigenetikailag egyik legvulnerábilisabb szakasza - elszenvedett teratogén hatások a postnatalis időszakban kialakuló krónikus betegségek kifejlődéséhez vezethetnek [47-49].

A PCOS kialakulásában is feltételezhető az in utero eredet, vagyis külső káros környezeti hatások következtében vagy éppen a hormonok kóros hatása következtében létrejöhet egy fenotípus-változás, amely az utódokban is megjelenhet.

Az egyik legjelentősebb ilyen kutatást $X u$ és mtsai publikálták 2011-ben [50]. Az epigenetikai változásokat olyan nőstény Rhesus majmokon vizsgálták, amelyeket a gesztációs idő alatt androgén hatásnak tettek ki. Visceralis zsírsejteken végezték vizsgálataikat. Ez a kísérleteik egyik erősségének mondható, mivel az epigenomot érintő változásokat célszerü olyan sejteken vizsgálni, amelyek leginkább érintettek az adott betegségben, ugyanis a DNS-metiláció szövetspecifikusan megy végbe. A DNS-t érintő változásokat újszülött és felnőtt majmok visceralis zsírszövetében is vizsgálták. Így megfigyelhették az in utero történő epigenetikai változásokat a megnövekedett androgén hatás következtében. A felnőttmintákból pedig következtethettek a postnatalis változásokra, mint az öregedés, környezeti és/vagy metabolikus hatásokra. Vizsgálataikban hét gén abberáns metilációját figyelték meg felnőtt majmokban [50]. Ezek a sejtszerkezet, illetve a sejtmembránfunkció kialakításában és fenntartásában játszanak szerepet. Újszülött tesztoszteronexpozíciónak kitett majmokon pedig a GLOl és DDBl gének voltak érintettek. Tehát in utero tesztoszteronnak és androszténdionnak kitett vizsgálati állatokban olyan epigenetikai változások mentek vége, amelyeknek szerepe lehet a PCOS kialakulásában [49, 50].

\section{Következtetések}

Számos kutatócsoport eredményei alapján a szteroidszintézis és az inzulin-anyagcsere részt vevő molekulái és receptorai polimorfizmusa, valamint az in utero tesztoszteronexpozíció is epigenetikailag jelentős etiológiai faktorként szerepelhet a PCOS létrejöttében. INSR-polimorfizmusok mint terápiás támadáspontok jelentős farmakológiai szereppel rendelkezhetnek. A lehetséges patogenetikai faktorok mellett fontos lenne prognosztikai markerek és a visceralis adipositas vizsgálata is. A PCOS korai szűrésére és az in utero faktorok vizsgálatára fontos felhívni a klinikusok figyelmét, mert ezáltal megelőzhetők lennének a létrejövő endokrinológiai és anyagcserezavarok rövid és hosszú távú következményei. 
Anyagi támogatás: A közlemény megírása, illetve a kapcsolódó kutatómunka anyagi támogatásban nem részesült.

Szerzői munkamegosztás: Minden szerző együttesen járult hozzá a kézirat megszövegezéséhez és az irodalmi áttekintéshez. H. Z., D. Cs.: Kézirat elkészítése. V. M., Sz. K., Sz. J.: Kézirat lektorálása. A cikk végleges változatát valamennyi szerző elolvasta és jóváhagyta.

Érdekeltségek: A szerző́knek nincsenek érdekeltségeik.

\section{Irodalom}

[1] Legro, R. S., Arslanian, S. A., Ehrmann, D. A., et al.: Diagnosis and treatment of polycystic ovary syndrome: an Endocrine Society clinical practice guideline. J. Clin. Endocrinol. Metab., 2013, 98(12), 4565-4592.

[2] Abbott, D. H., Barnett, D. K., Bruns, C. M., et al.: Androgen excess fetal programming of female reproduction: a developmental aetiology for polycystic ovary syndrome? Hum. Reprod. Update, $2005,11(4), 357-374$.

[3] Attaoua, R., Ait El Mkadem, S., Radian, S., et al.: FTO gene associates to metabolic syndrome in women with polycystic ovary syndrome. Biochem. Biophys. Res. Commun., 2008, 373(2), 230-234.

[4] Balen, A.: The pathophysiology of polycystic ovary syndrome: trying to understand PCOS and its endocrinology. Best Pract. Res. Clin. Obstet. Gynaecol., 2004, 18(5), 685-706.

[5] Barry, J. A., Azizia, M. M., Hardiman, P. J., et al.: Risk of endometrial, ovarian and breast cancer in women with polycystic ovary syndrome: a systematic review and meta-analysis. Hum. Reprod. Update, 2014, 20(5), 748-758.

[6] Broekmans, F. J., Knauff, E. A., Valkenburg, O., et al.: PCOS according to the Rotterdam consensus criteria: Change in prevalence among WHO-II anovulation and association with metabolic factors. BJOG, 2006, 113(10), 1210-1217.

[7] Conway, G., Dewailly, D., Diamanti-Kandarakis, E., et al.: The polycystic ovary syndrome: a position statement from the European Society of Endocrinology. Eur. J. Endocrinol., 2014, $171(4)$, P1-P29.

[8] Prapas, N., Karkanaki, A., Prapas, I., et al.: Genetics of polycystic ovary syndrome. Hippokratia, 2009, 13(4), 216-223.

[9] Unluturk, U., Harmanci, A., Kocaefe, C., et al.: The genetic basis of the polycystic ovary syndrome: a literature review including discussion of PPAR- $\gamma$. PPAR Res., 2007, 2007, ID 49109.

[10] Franks, S., Gilling-Smith, C., Gharani, N., et al.: Pathogenesis of polycystic ovary syndrome: evidence for a genetically determined disorder of ovarian androgen production. Hum. Fertil. (Camb.), 2000, 3(2), 77-79.

[11] Gharani, N., Waterworth, D. M., Batty, S., et al.: Association of the steroid synthesis gene CYPIIa with polycystic ovary syndrome and hyperandrogenism. Hum. Mol. Gen., 1997, 6(3), 397-402.

[12] Diamanti-Kandarakis, E., Bartzis, M. I., Bergiele, A. T., et al.: Microsatellite polymorphism (tttta) at -528 base pairs of gene CYPIla influences hyperandrogenemia in patients with polycystic ovary syndrome. Fertil. Steril., 2000, 73(4), 735-741.

[13] Gaasenbeek, M., Powell, B. L., Sovio, U., et al.: Large-scale analysis of the relationship between CYPIIA promoter variation, polycystic ovarian syndrome, and serum testosterone. J. Clin. Endocrinol. Metab., 2004, 89(5), 2408-2413.

[14] Ewens, K. G., Jones, M. R., Ankener, W., et al.: FTO and MC4R gene variants are associated with obesity in polycystic ovary syndrome. PLoS ONE, 2011, 6(1), el6390.

[15] Goodarzi, M. O., Shah, N. A., Antoine, H. J., et al.: Variants in the $5 \alpha$-reductase type 1 and type 2 genes are associated with polycys- tic ovary syndrome and the severity of hirsutism in affected women. J. Clin. Endocrinol. Metab., 2006, 91(10), 4085-4091.

[16] Hwang, J. Y., Lee, E. J., Go, M. J., et al.: Genome-wide association study identifies GYS2 as a novel genetic factor for polycystic ovary syndrome through obesity-related condition. J. Hum. Genet., 2012, 57(10), 660-664.

[17] Escobar-Morreale, H. F., San Millán, J. L., Smith, R. R., et al.: The presence of the 21-hydroxylase deficiency carrier status in hirsute women: phenotype-genotype correlations. Fertil. Steril., 1999, 72(4), 629-638.

[18] Glintborg, D., Hermann, A. P., Brusgaard, K., et al.: Significantly higher adrenocorticotropin-stimulated cortisol and 17-hydroxyprogesterone levels in 337 consecutive, premenopausal, caucasian, hirsute patients compared with healthy controls. J. Clin. Endocrinol. Metab., 2005, 90(3),1347-1353.

[19] Wickenheisser, J. K., Nelson-DeGrave, V. L., McAllister, J. M.: Dysregulation of cytochrome P450 17a-hydroxylase messenger ribonucleic acid stability in theca cells isolated from women with polycystic ovary syndrome. J. Clin. Endocrinol. Metab., 2005, 90(3), 1720-1727.

[20] Gharani, N., Waterworth, D. M., Williamson, R., et al.: 5 'polymorphism of the CYP17 gene is not associated with serum testosterone levels in women with polycystic ovaries. J. Clin. Endocrinol. Metab., 1996, 81(11), 4174.

[21] Techatraisak, K., Conway, G. S., Rumsby, G.: Frequency of a polymorphism in the regulatory region of the $17 \alpha$-hydroxylase17,20-lyase (CYP17) gene in hyperandrogenic states. Clin. Endocrinol., 1997, 46(2), 131-134.

[22] Kahsar-Miller, M., Boots, L. R., Bartolucci, A., et al.: Role of a CYP17 polymorphism in the regulation of circulating dehydroepiandrosterone sulfate levels in women with polycystic ovary syndrome. Fertil. Steril., 2004, 82(4), 973-975.

[23] Chamberlain, N. L., Driver, E. D., Miesfeld, R. L.: The length and location of CAG trinucleotide repeats in the androgen receptor $\mathrm{N}$-terminal domain affect transactivation function. $\mathrm{Nu}-$ cleic Acids Res., 1994, 22(15), 3181-3186.

[24] Mifsud, A., Ramirez, S., Yong, E. L.: Androgen receptor gene CAG trinucleotide repeats in anovulatory infertility and polycystic ovaries. J. Clin. Endocrinol. Metab., 2000, 85(9), 34843488.

[25] Hickey, T., Chandy, A., Norman, R. J.: The androgen receptor CAG repeat polymorphism and X-chromosome inactivation in Australian Caucasian women with infertility related to polycystic ovary syndrome. J. Clin. Endocrinol. Metab., 2002, 87(1), 161165.

[26] Hogeveen, K. N., Talikka, M., Hammond, G. L.: Human sex hormone-binding globulin promoter activity is influenced by a $(\text { TAAAA })_{n}$ repeat element within an Alu sequence. J. Biol. Chem., 2001, 276(39), 36383-36390.

[27] Xita, N., Tsatsoulis, A., Chatzikyriakidou, A., et al.: Association of the (TAAAA) $)_{n}$ repeat polymorphism in the sex hormonebinding globulin (SHBG) gene with polycystic ovary syndrome and relation to SHBG serum levels. J. Clin. Endocrinol. Metab., $2003,88(12), 5976-5980$

[28] Cousin, P., Calemard-Michel, L., Lejeune, H., et al.: Influence of $S H B G$ gene pentanucleotide TAAAA repeat and D327N polymorphism on serum sex hormone-binding globulin concentration in hirsute women. J. Clin. Endocrinol. Metab., 2004, 89(2), 917-924.

[29] Furui, K., Suganuma, N., Tsukahara, S., et al.: Identification of two point mutations in the gene coding luteinizing hormone (LH) $\beta$-subunit, associated with immunologically anomalous LH variants. J. Clin. Endocrinol. Metab., 1994, 78(1), 107-113.

[30] Okuda, K., Yamada, T., Imoto, H., et al.: Antigenic alteration of an anomalous human luteinizing hormone caused by two chorionic gonadotropin-type amino-acid substitutions. Biochem. Biophys. Res. Communic., 1994, 200(1), 584-590. 
[31] Haavisto, A. M., Pettersson, K., Bergendabl, M., et al.: Occurrence and biological properties of a common genetic variant of luteinizing hormone. J. Clin. Endocrinol. Metab., 1995, 80(4), 12571263.

[32] Rajkhowa, M., Talbot, J. A., Jones, P. W., et al.: Prevalence of an immunological LH $\beta$-subunit variant in a UK population of healthy women and women with polycystic ovary syndrome. Clin. Endocrinol., 1995, 43(3), 297-303.

[33] Waterworth, D. M., Bennett, S. T., Gharani, N., et al.: Linkage and association of insulin gene VNTR regulatory polymorphism with polycystic ovary syndrome. Lancet, 1997, 349(9057), 986990.

[34] Calvo, R. M., Tellería, D., Sancho, J., et al.: Insulin gene variable number of tandem repeats regulatory polymorphism is not associated with hyperandrogenism in Spanish women. Fertil. Steril., 2002, 77(4), 666-668.

[35] Sorbara, L. R., Tang, Z., Cama, A., et al.: Absence of insulin receptor gene mutations in three insulin-resistant women with the polycystic ovary syndrome. Metabolism, 1994, 43(12), 15681574.

[36] Talbot, J. A., Bicknell, E. J., Rajkhowa, M., et al.: Molecular scanning of the insulin receptor gene in women with polycystic ovarian syndrome. J. Clin. Endocrinol. Metab., 1996, 81(5), 19791983.

[37] Urbanek, M., Woodroffe, A., Ewens, K. G., et al.: Candidate gene region for polycystic ovary syndrome on chromosome 19p13.2. J. Clin. Endocrinol. Metab., 2005, 90(12), 6623-6629.

[38] Siegel, S., Futterweit, W., Davies, T. F., et al.: A C/T single nucleotide polymorphism at the tyrosine kinase domain of the insulin receptor gene is associated with polycystic ovary syndrome. Fertil. Steril., 2002, 78(6), 1240-1243.

[39] Jellema, A., Zeegers, M. P., Feskens, E. J., et al.: Gly972Arg variant in the insulin receptor substrate-1 gene and association with type 2 diabetes: a metaanalysis of 27 studies. Diabetologia, 2003, 46(7), 990-995.

[40] El Mkadem, S. A., Lautier, C., Macari, F., et al.: Role of allelic variants Gly972Arg of IRS-1 and Gly1057Asp of IRS-2 in moderate-to-severe insulin resistance of women with polycystic ovary syndrome. Diabetes, 2001, 50(9), 2164-2168.

[41] Ehrmann, D. A., Tang, X., Yoshiuchi, I., et al.: Relationship of insulin receptor substrate- 1 and -2 genotypes to phenotypic fea- tures of polycystic ovary syndrome. J. Clin. Endocrinol. Metab., 2002, 87(9), 4297-4300.

[42] Villuendas, G., Botella-Carretero, J. I., Roldán, B., et al.: Polymorphisms in the insulin receptor substrate-1 (IRS-1) gene and the insulin receptor substrate-2 (IRS-2) gene influence glucose homeostasis and body mass index in women with polycystic ovary syndrome and non-hyperandrogenic controls. Hum. Reprod., 2005, 20(11), 3184-3191.

[43] Dilek, S., Ertunc, D., Tok, E. C., et al.: Association of Gly972Arg variant of insulin receptor substrate-1 with metabolic features in women with polycystic ovary syndrome. Fertil. Steril., 2005, $84(2), 407-412$

[44] Ertunc, D., Tok, E. C., Aktas, A., et al.: The importance of IRS-1 Gly972Arg polymorphism in evaluating the response to metformin treatment in polycystic ovary syndrome. Hum. Reprod., 2005, 20(5), 1207-1212.

[45] Rosenfield, R. L., Barnes, R. B., Cara, J. F., et al.: Dysregulation of cytochrome P450cl7 $\alpha$ as the cause of polycystic ovarian syndrome. Fertil. Steril., 1990, 53(5), 785-791.

[46] Vassiliadi, D. A., Barber, T. M., Hughes, B. A., et al.: Increased $5 \alpha$-reductase activity and adrenocortical drive in women with polycystic ovary syndrome. J. Clin. Endocrinol. Metab., 2009, 94(9), 3558-3566.

[47] Vink, J. M., Sadrzadeh, S., Lambalk, C. B., et al.: Heritability of polycystic ovary syndrome in a Dutch twin-family study. J. Clin. Endocrinol. Metab., 2006, 91(6), 2100-2104.

[48] Wojciechowski, P., Lipowska, A., Rys, P., et al.: Impact of FTO genotypes on BMI and weight in polycystic ovary syndrome: a systematic review and meta-analysis. Diabetologia, 2012, 55(10), 2636-2645.

[49] Xu, N., Azziz, R., Goodarzi, M. O.: Epigenetics in polycystic ovary syndrome: a pilot study of global DNA methylation. Fertil. Steril., 2010, 94(2), 781-783.el.

[50] Xu, N., Kwon, S., Abbott, D. H., et al.: Epigenetic mechanism underlying the development of polycystic ovary syndrome (PCOS)-like phenotypes in prenatally androgenized rhesus monkeys. PLoS ONE, 2011, 6(11), e27286.

(Szili Károly dr., Szeged, Somogyi u. 4., 6720 e-mail: szilikaroly@gmail.com)

Az Orvosi Hetilap egyes számai megvásárolhatók a Mediprint Orvosi Könyvesboltban. Cím: Budapest V., Múzeum krt. 17. - Telefon: 317-4948 